\title{
İstatistik Öğretiminde Yeni Bir Yaklaşım: Doğada Uygulamalı İstatistik
}

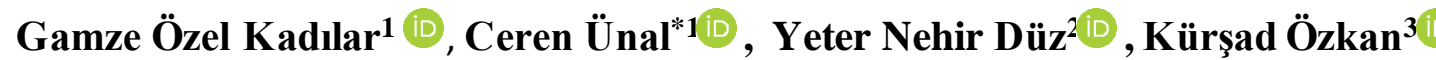

Özet: Günümüz Türkiye'sinde istatistik konuları ağırlıklı olarak matematik öğretim programlarında yer almaktadır. Son yıllardaki teknolojik ve bilimsel ilerlemeler sonucunda yığınlar halindeki ham veri ve bilgi trafiği nedeniyle meydana gelen karmaşa verilerin analizi ve yorumlanmasını daha da önemli hale getirmiştir. Bu yüzden, öğretim programlarında istatistiksel yöntem ve araçlara daha çok ihtiyaç duyulmaktadır. Bu çalışmada, TÜBİTAK 4004 Doğa Eğitimi ve Bilim Okulları kapsamında gerçekleştirilen "İstatistiği Doğada Öğren” projesinin istatistik öğretiminde sağladığı ve sağlayacağ1 faydalar üzerinde durulmuştur. Araştırmanın örneklemini projeye katılan farklı branşlardaki 36 ögretmen oluşturmaktadır. Proje kapsamında, istatistiğin doğa uygulamaları ve örnekleri ile ilgili etkinlikler gerçekleştirilmiştir. Projenin öğretmenler üzerindeki etkisini ölçmek için proje araștırmacıları tarafından oluşturulan etkinlik değerlendirme formları, röportajlar ve mini test uygulamaları kullanılmıştır. Ayrıca, öğretmenlerin proje sonrasındaki kurgusal eğitim örnekleri ve yaptıkları görsel sanat çalışmaları incelenmiştir. Projedeki etkileşimli ve doğaya dayalı istatistiksel uygulamaların ve verinin yazılımlar ile görselleştirilerek aktarılmasının öğretmenleri pozitif yönde etkilediği, öğretmenlerin öğrenme ve araştırma isteklerini arttırdığg gözlenmiştir.

Anahtar Kelimeler: İstatistik Eğitimi, istatistik okuryazarlık, doğa eğitimi, veri görselleştirme, veri bilimi

\section{Learn Statistics in Nature}

Özet: Today's statistics topics are located in more mathematics curriculum in Turkey. As a result of technological and scientific advances in recent years, the complexity caused by the raw data and information traffic has made the analysis and interpretation of the data even more important. Therefore, statistical methods and tools are needed more in education programs. In this study, the benefits of "Learn Statistics in Nature" project realized within the scope of TÜBİTAK 4004 Nature Education and Science Schools in statistics teaching are emphasized. The sample of the research consists of 36 teachers from different branches participating in the project. Within the scope of the project, activities related to the natural applications and examples of statistics were executed. In order to measure the impact of the project on teachers, activity evaluation forms, interviews and mini-tests created by the researchers were used. In addition, teachers' post-project fictional education examples and their visual arts were analyzed. It was observed that the interactive and nature-based statistical applications in the project and the visualization of the data with software positively affected the teachers and increased their learning and research desire.

Keywords: Statistics Education, statistical literacy, nature education, data visualization, data science.

${ }^{1}$ Address (adres): Hacettepe Üniversitesi, Fen Fakültesi, İstatistik Bölümü, 06800 Beytepe, Ankara, Türkiye

${ }^{2}$ Address (adres): Şehit Osman Yılmaz Anadolu İmam Hatip Lisesi, Milli Eğitim Bakanlığı, İstanbul, Türkiye

${ }^{3}$ Address (adres): Isparta Uygulamalı Bilimler Üniversitesi, Orman Fakültesi, Toprak İlmi ve Ekolojisi Anabilim Dalı Başkanlığı, Isparta, Türkiye

*Corresponding author (sorumlu yazar): cerenunal@hacettepe.edu.tr

Citation (atıf): Özel Kadılar, G.,Ünal, C., Düz, Y. N., Özkan, K. (2021). İstatistik Öğretiminde Yeni Bir Yaklaşım: Doğada Uygulamalı İstatistik. Bilge International Journal of Science and Technology Research, 5(2): 124-138. 


\section{GíRiş}

İstatistik, günlük hayatı yöneten verileri toplama, düzenleme ve bu düzenlenen bilgilerin uygun grafik ve tablolarla sunulmas1, sunulan bu bilgilerin yorumlanması ve analizini sağlayan, birçok bilim dalına yardımcı olan bir disiplindir. İstatistik ile alakalı temel kavramlar ile ista tistik dilinin bilinmesi, anlaşılması, kullanılması ve elde edilen istatistiksel sonuçların eleştirel bir çerçevede yorumlanabilmesi ise istatistik okuryazarlığı olarak tanımlanabilir. Büyük veri çağı olarak da adlandırılan günümüzde, istatistik okuryazarı bireylere olan ihtiyaç gün geçtikçe daha da artmaktadır (Yenilmez, 2016). Buna paralel olarak, Türkiye'de de büyük veri ve bilgisayar teknolojisinin gelişimi ile istatistik ve istatistiksel düşünmeye olan ilgi giderek artmaktadır.

İstatistik, genellikle matematiğin bir alanı olarak kabul edilmesine rağmen matematiksel düşünce yeteneğinden farklılaştığı unsurlar söz konusudur. Malik (2015) yaptığı çalışmasında yüksek istatistik kaygı düzeyine sahip olan öğrencilerin düşük matematik kaygı düzeyine sahip olduğu dolayısıyla istatistik ve matematiğin öğrenci için zorluk düzeylerinde farklı olduğu sonucuna ulaşmıştır (Akkoç ve Yeşildere, 2015). Aynı zamanda, teknolojiyle birlikte istatistik öğretiminde histogram ve çizelge oluşturma ve kapsamlı matematiksel işlemlerin teknoloji yardımıyla kolaylıkla elde edilmesi sonucunda öğrencilerin bu işlemler yerine kavramlara odaklanması sağlanmıştır (Chance vd., 2007). Bu da, istatistik eğitiminin matematik eğitiminden farklı olduğunun bir göstergesidir. Genel olarak bakıldığında ise, istatistik öğretimi üzerine yapılan çalışmalar, öğrencilerin çoğunlukla istatistik kaygısına sahip olduğunu kanıtlamaktadır (Akkoç ve Yeşildere, 2015). Bu sonuçlar göz önünde bulundurulduğunda, istatistik öğretiminin sağlanmasında kullanılabilecek geleneksel sınıf içi öğretim yöntemlerinden farklı teknik ve yeni görsel formatlarının üretilmesi ve bu konuda gelişim sa ğlanması büyük önem arz etmektedir.

Günümüz eğitim ortamlarında birçok öğretim modeli, yöntemi, teknik ve araç gereçleri ögretim içeriklerinin öğrenciye aktarılmasında kullanılmaktadır. Öğrencilerin algılama ve de öğrenme süreçlerini kolaylaştırmada, motivasyonlarının artırılmasında, öğretilenlerin canlandırılmasında, öğretim sürecinin zenginleştirilmesinde, bilgilerin pekiştirilerek kalıcı öğrenmelerin sağlanmasında materyal kullanımı önemlidir (Aslan ve Doğdu, 1993; Erden, 1998; Demiralp, 2007). Öğretim, teknik, materyal ve araç gereçlerde uygun olanların seçimi, öğretimin hedeflerine ulaşılmasında etkili bir metottur. Yapılan araştırmalar sonucunda görülmüştür ki, öğretimin \%83'ü görme, \%11'i işitme, \%3,5'i koku, $\% 1,5$ 'i dokunma ve \%1'i ise tatma yoluyla öğrenilmektedir (Kaya, 2006).

Doğanın laboratuvarortamı ola rak kullanıldı̆̆ı uygula m a lı doğa eğitimleri, bireylerin araştırma ve problem çözme ile ilgili beceriler edinmesini amaçlayan ve aktif katılım sonucu kalıcı öğrenmeyi sağlayan bir öğretim yaklaşımıdır (Ozaner 2004). TÜBİTAK, kamu çalışanlarından öğrencilere kadar geniş bir hedef kitlenin bilime dokunmaları amacıyla 4004-Doğa Eğitimi ve Bilim Okulları isimli programını uygulamaya koymuştur. Bu program kapsamında desteklenen etkinlikler, örgün eğitim programlarında doğa-çevre konularındaki yetersizlikleri gidermek, doğa dostu bireyleri topluma kazandırmak ve farklı bilim dalları ile doğa arasında bağlantı kurmak ve a kta rmak a maçla rıyla önemli fırsa tlar sunmaktadır (Oğurlu vd., 2013). Bu eğitimlerdeki genel amaç, bilgiyi topluma a nlaşı1ır bir şekilde aktarmaktır. Bu a maç doğrultusunda da bilgiyi olabildiğince görselleştirilerek, etkileşimli uygulamalarla destekleyerek ve günlük hayatla bilimsel gerçeklerin ne kadar ilişkili olduğunu belirterek, bilimin ne kadar eğlenceli olabileceği de gösterilmektedir. Bu doğrultuda, klasik eğitim metotlarını kullanarak fazla bilgi aktarmak yerine temel bilimsel olguların fark edilmesi sağlanarak merak duygusu, araştırma ve öğrenme isteğinin ön plana çıkartılması önem teşkil etmektedir (Tekbıyık vd., 2013).

TÜBİTAK 4004-Doğa Eğitimi ve Bilim Okulları kapsamındaki projelerin sonuçla rına da ir ya pılan ça lışmalar incelendiğinde, gerçekleştirilen projelerde yer alan etkinlikler sonucunda katılımcıların çevreye karşı sorumluluklarının arttığı (Güler, 2009; Özdemir, 2010); çevresel tutum ve bilinç açısından önemli derecede katkı sağlandığı (Keleş vd., 2010); öğrenme ortamlarını daha verimli hale getirdiği (Buluş-Kırıkkaya vd., 2011); doğal çevre, çevre kirliliği ve canlı türlerine yönelik duyarlılıkların arttığı (Feyzioğlu vd., 2012); ilginç, eğlenceli, farklı ve faydalı hale geldiği (Hırça, 2013); bilgileri davranışa dönüştürmeyi kolaylaştırdığı (Oğurlu vd., 2013); bilime karşı pozitif bir tutum geliştirmede katkı sağladığı (Akay, 2013; Tekbıyık vd. 2013); fen ve hayat konularının ilişkisini kurma konusunda yardımcı olabileceği (Marulcu vd., 2014) belirtilmektedir.

Literatür incelendiğinde istatistik ve doğa eğitimi içerikli herhangi bir bilimsel çalışma veya TÜBİTAK 4004 kapsamında desteklenen Doğa Eğitimi ve Bilim Okulu olmadığı sonucuna ulaşılmıştır. Ancak TÜBİTAK 2237-A kapsamında önerilen "Doğa Bilimlerinde İstatistiksel Modelleme Teknikleri ve Uygulamaları" adlı etkinlik incelenmiş ve bu eğitime katılmak isteyen öğretmen sayısının oldukça fazla olduğu görülmüştür (TÜBİTAK, 2019a). Ancak bu eğitim peyzaj, orman, endüstri, gıda gibi mühendislik alanlarına daha uygun niteliktedir ve öğretmenlere yönelik istatistik içerikli bir doğa eğitimine rastlanmamıştır. Tüm bu sonuçlar göz önünde bulundurularak TÜBİTAK 4004 Doğa Eğitimi ve Bilim Okulları kapsamında "İstatistiği Doğa da Öğren" adlı proje 2019 yılında önerilmiştir (TÜBİTAK, 2019b). 2020 yılında desteklenen bu proje, 19-24 Ağustos 2020 tarihleri arasında Ilgaz Da ğı Milli Parkı, Dipsiz Göl Tabiat Parkı, Pınarbaşı Horma Kanyonu ve Ilıca Şelalesi’nde gerçekleştirilmiştir. $\mathrm{Bu}$ proje kapsamında istatistik ve doğa ile ilgili bilimsel çalışmaların yanı sıra, doğa bilimcilerin kullandığı PAST istatistiksel yazılımı ile katılımcı öğretmenlerin doğadan elde edilen verileri analiz ederek yorumlamaları sağlanmıştır. Ayrıca müzik, görsel sanatlar ve coğrafya a lanları ile ilgili faaliyetler de gerçekleştirilmiştir.

Bu çalışmada "İstatistiği Doğada Öğren" isimli projenin sonuçlarına ve istatistik ögretiminin sınıf dışında doğadan yararlanarak aktarılmasının faydalarına yer verilmiştir. Bölüm 2'de İstatistik Biliminin Türkiye'de öğretim programlarındaki yeri üzerinde durulmuştur. Bölüm 3 'te "İstatistiği Doğada Öğren” projesinde yer alan etkinliklere, katılımcilara uygulanan proje değerlendirme anketi sonuçlarına, röportajlara, kurgusal ve uygulamalı eğitim 
içeriklerine yer verilmiştir. Bölüm 4'te ise çalışmaların sonuç ve tartışma ları üzerinde durulmuştur.

\section{ISTATISTIK BİLIMININ ÖĞRETIM PROGRAMLARINDAKI YERİ}

İstatistik, günlük yaşamda yararlı olması ve istatistiksel bilgilerin istatistiksel okuryazarlıkla ilişkisi, diğer disiplinlerde de yararlanılan bir araç olması, eleştirel düşünmeyi geliştirmedeki öneminin kavranması ile matematik ögretim programlarında ilgi odağı haline gelmiştir (Garfield, 1995; Rumsey, 2002; Watson, 2006). Ayrıca toplumdaki bireylerin de istatistiksel bilgileri anlama ve kullanma ihtiyacı okul ögretim programlarında ve iş ile günlük hayatlarda gün giderek artmaktadır (Koparan ve Akınc1, 2015). Bu nedenle büyük verilerle ile daha sık karşılaştığımız ça ğımızda istatistik okuryazarlığı olarak adlandirılan toplumun her seviyesindeki bireylerin günlük yaşamdaki istatistiksel sonuç ve çıkarsamaları kavrayabilecekleri yeni bir öğretim tanımı günümüzde popüler hale gelmiştir.

İstatistik okuryazarlığı ile ilgili literatürde birçok tanım bulunmaktadır. Gal (2004)'e göre, bireylerin istatistiksel veriler ile ilgili sonuçları yorumlama, bunları eleştirel bakış açısı ile değerlendirme ve sonuçlarına ait görüşlerini dile getirme yeteneğini ifade etmektedir. Wallman (1993), istatistiksel sonuçları anlayarak eleştirel olarak değerlendirebilmeyi istatistik okuryazarlığı olarak tanımlamaktadır. Özmen (2015) ise, istatistiksel temel kavramlarının bilinmesi, tablo ve grafiklerle yorumlanabilmesi, veriler üzerinde çıkarsama yapılabilmesi, etkili karar alınabilmesi, eleştirel bir yaklaşım sergilenmesi ve sunulan bağlamlar üzerinden yorum yapılabilmesi olarak ifade etmiștir. Genel olarak bakıldığında ise, istatistik ögretiminin temel unsurlarının verinin toplanması (Cobb ve Moore, 1997), verilerin analizi (Pfannkuch ve Wild, 2004), veri kümelerinin yorumlanması ve genelleștirilmesi (Garfield ve Ben-Zvi, 2008) olduğu söylenebilir.

İstatistik öğretimi ülkemizde orta öğretim matematik müfredatında yer almaktadır. Tablo 1'de 1926 yılından bugüne dek matematik müfredatında yer alan istatistik eğitimi özetlenmiştir. Tablo 1 incelendiğinde, İstatistik içerikli konuların 1949 yılından itibaren orta okulmatematik dersi öğretim programlarından yer aldığı görülmektedir. Ancak verilerden çıkarsama ve genelleme yapma amacı üzerinde yeterince durulma dı ğı görülmektedir.

Tablo 2'de tablo ve grafik gibi veri görselleştirme araçlarının yıllara göre öğretim programlarındaki yeri üzerinde durulmuştur. Buna göre, günümüzde veri görselleştirme yöntemlerinin giderek artan biçimde öğretim programlarında yer aldığı görülmektedir. Özellikle 2005 yılından itibaren veri görselleştirme ile ilgili kazanımların ortaokul öğretimde ilk yıllara doğru kayarak daha ayrıntılı olarak verildiği ve öğrencilerin daha erken yaşlardan itibaren bu veri görselleştirme araçlarından daha yoğun biçimde kullanabilmelerinin hedeflendiği söylenebilir.

Günümüzde öğretim programlarında veri bilimi ile ilgili en önemli amaç, öğrencilerin a raştırma bakış açısı ve becerileri kazanacak biçimde eğitilmesidir. Tablo 3 incelendiğinde, 2005 y1lından itibaren öğretim programlarında değişkenlerin belirlenmesi ve tanımı, verilerin toplanması için gereklilikler, veriye uyan görselleştirme araçlarının tespiti ve yorumlama becerilerinin kazanım seviyesinde yer aldığı görülmektedir. Ülkemizde, tüm ülkelerde olduğu gibi, matematik öğretim programlarında ihtiyaç duyulması durumunda yeniden düzenlemeler yapılmaktadır. Değişiklikler, en son 2005 ve 2013 yıllarında yapılmıştır. Yenilenen bu programlar incelendiğinde, farklı sınıf düzeylerinde verileri okuma ve temsil etme, merkezi yayılım ve eğilim ölçülerinden yararlanma, verilerden tahmin ve çıkarımlar elde etme ve olasılık hesaplanı gibi istatistiksel becerilere eskiye oranla daha çok yer verildiği dikkat çekmektedir (MEB, 2009; MEB, 2013). 
Tablo 1. Yıllara Göre Ortaokul Matematik Dersi Öğretim Programlarında İstatistik ile İlgili Amaçların Programlardaki Yeri

\section{Ortaokul Matematik Dersi Öğretim Programları}

\section{Amaçlar}

๙ু

\begin{tabular}{|c|c|c|c|c|c|c|c|c|c|c|c|}
\hline $\begin{array}{l}\text { Kazanilan becerileri hayatla } \\
\text { ilişkilendirme }\end{array}$ & - & - & - & $\checkmark$ & $\checkmark$ & $\checkmark$ & $\checkmark$ & $\checkmark$ & $\checkmark$ & $\checkmark$ & $\checkmark$ \\
\hline Verileri görselleştirme & - & - & - & $\checkmark$ & $\checkmark$ & $\checkmark$ & $\checkmark$ & $\checkmark$ & $\checkmark$ & $\checkmark$ & $\checkmark$ \\
\hline Veri toplama & - & - & - & $\checkmark$ & $\checkmark$ & $\checkmark$ & $\checkmark$ & $\checkmark$ & $\checkmark$ & $\checkmark$ & $\checkmark$ \\
\hline Veri analizi & - & - & - & $\checkmark$ & $\checkmark$ & $\checkmark$ & $\checkmark$ & $\checkmark$ & $\checkmark$ & $\checkmark$ & $\checkmark$ \\
\hline $\begin{array}{l}\text { Veri analizlerini yorumlama, } \\
\text { çıkarsama ve genelleme yapabilme }\end{array}$ & - & - & - & - & - & - & - & - & - & - & - \\
\hline
\end{tabular}

Tablo 2. Ortaokul Matematik Dersi Öğretim Programlarında Yer Alan Veri Görselleştirme Yöntemleri ve Öğretilen Sınıf Seviyesi

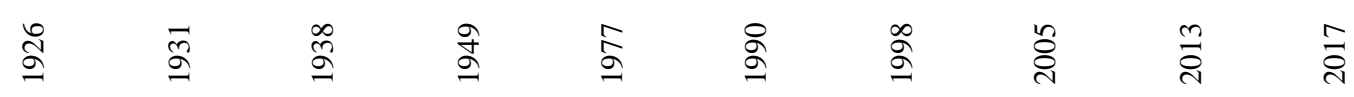

\begin{tabular}{|c|c|c|c|c|c|c|c|c|c|c|}
\hline Siklık çizelgesi & - & - & - & - & - & 7 & 7 & 6 & 5 & 5 \\
\hline Ağaç şemas1 & - & - & - & - & - & - & - & - & 5 & - \\
\hline Sütun grafiği & - & - & - & - & 7 & 7 & 7 & 6 & 5 & 5 \\
\hline $\begin{array}{l}\text { İki boyutlu sütun ve çizgi } \\
\text { grafikleri }\end{array}$ & - & - & - & - & - & - & - & 7 & 6 & 6 \\
\hline Pasta grafiği & - & - & - & - & 7 & 7 & 7 & 7 & 7 & 7 \\
\hline Çizgi grafiği & - & - & - & - & 7 & 7 & 7 & 7 & 7 & 7 \\
\hline Histogram & - & - & - & - & - & - & - & 8 & 8 & - \\
\hline
\end{tabular}

Tablo 3. Araştırma yaklaşımı ile ilgili kazanımların programlardaki yeri

Ortaokul Matematik Dersi Öğretim Programları

\begin{tabular}{|c|c|c|c|c|c|c|c|c|c|}
\hline ๙઼ & $\vec{\sigma}$ & $\stackrel{\infty}{\infty}$ & $\stackrel{g}{\text { g }}$ & ลิ & 요 & $\stackrel{\infty}{\circ}$ & ஜ̊ & $\frac{m}{\grave{d}}$ & $\bar{\sigma}$ \\
\hline
\end{tabular}

\footnotetext{
Araştırma

değişkenlerinin

belirlenmesi
}

\begin{tabular}{|c|c|c|c|c|c|c|c|c|c|c|}
\hline $\begin{array}{l}\text { Değişkenler ile ilgili bilgi } \\
\text { toplanması }\end{array}$ & - & - & - & - & - & - & - & $\checkmark$ & $\checkmark$ & $\checkmark$ \\
\hline $\begin{array}{l}\text { Verilerin } \\
\text { görselleştirilmesi }\end{array}$ & - & - & - & - & - & - & - & $\checkmark$ & $\checkmark$ & $\checkmark$ \\
\hline Verilerin yorumlanmas1 & - & - & - & - & - & - & - & - & - & - \\
\hline $\begin{array}{l}\text { İki veri grubu ile çalışma } \\
\text { yapma }\end{array}$ & - & - & - & - & - & - & - & - & $\checkmark$ & $\checkmark$ \\
\hline
\end{tabular}


İstatistik öğretiminde merkezi eğilim ve yayılım ölçüleri gibi veri kümesini tanımlamayı sağlayan ölçüler de giderek programlarda daha çok yer almaktadır. Tablo 1-3'te de görüldüğü gibi birçok ülkeye benzer olarak Türkiye'deki öğretim programlarında da istatistik alanına ve düşüncesinde artan bir ilgi görülmektedir. Ancak öğretim programlarında istatistik ile ilgili içeriklerin öğretimi ve öğrenimi ile ilgili konulara eğilmeye ve bu eğitimin verimli bir şekilde gerçekleştirilebileceği çeşitli öğretim ortamları ve aynı zamanda uygulamaları geliştirecek çalışmalara ihtiyaç duyulmaktadır.

Öğrencilere temel istatistik formüllerini ezberletmekten kurtaran, bilimsel düşünme yeteneğini kazandıran, araştırmacı, eleştirel bakış açısına sahip, İstatistik öğretimini genç yaşlarda bireylere aşılayabilen öğretim programları ancak pedagojik yeterliliği yüksek, doğa, istatistik ve veri bilimi konulan hakkında bilgili ve bilinçli öğretmenler ile sağlanabilir. İstatistik tüm bilim dallarına yardımc1 olduğundan sadece matematik ile sınırlandırılmayıp öğretimdeki tüm branşlarda faydalanılabilecek bir bilimdir. Öğrencilerin dinleyici konumunda olduğu, soru-cevap veya düz anlatım gibi geleneksel öğretim yöntemlerinden çoğunlukla yararlanılan Sosyal Bilgiler dersi için istatistiksel grafik ve tablolar, temel bilgilerin öğrenciye aktarılmasında ideal bir görsel ögretim yöntemi olarak düşünülebilir (Koparan, 2015). Bu nedenle geleceğin öğrencilerini yetiştiren öğretmenlerin TÜBİTAK 4004 Doğa Eğitimi ve Bilim Okulları kapsamındaki "İstatistiği Doğada Öğren" projesine katılımlarında matematik alanı ile ilgili bir sınırlandırma yapılmamış tüm branşlardaki öğretmenlerin katılımları sağlanmıştır.

Günümüzde problem çözme, örnek olay, drama, rol oynama ve beyin fırtınası gibi birçok öğretim yöntem ve tekniği bulunmasına rağmen okullardaki öğretim uygulamaları genellikle ders kitabına bağlı ve ögretmen merkezlidir (Altınışık ve Orhan, 2002). Bunun yanında öğretim esnasında sıklıkla kullanılan eğitsel araç gereçler incelendiğinde küre, harita ve kitap gibi geleneksel materyallerin dışına çıkılamadığı görülmektedir. Veri görselleştirme etkinliklerinde doğadan yararlanılması; ögretimin pratik olarak tasarlanmasını, soyut kavramların somutlaştırılmasını ve öğrenenin bilgiyi analiz ederek keşfetmesini sağladığından öğretimin daha etkili ve ilgi çekici hale gelmesini mümkün kılabilir.

Hayat bilgisi ve fen ve teknoloji alanlarıyla ilgili literatür incelendiğinde; verimli bir öğretim sürecinin oluşması ve öğrencilerin öğrenmelerinin kolaylaştırılabilmesi için yaparak-yaşayarak öğrenme, ya pılandırmacı yakla şım, aktif öğrenme ve sınıf dışı öğrenme gibi öğretme etkinlikleri önemli bir yer teşkil etmektedir (Akay, 2013). Bunlarla birlikte öğretim etkinliklerinde bilişim teknolojilerinden yararlanılması, öğretimde farklı duyulara hitap eden birçok materyalin kullanılabilmesini mümkün kılarak bireylerin öğrenmelerine olumlu yönde katk1 sağlayabilecek ve öğretimi geleneksel yöntemlere göre daha etkili hale getirebilecektir. Dolayısıyla istatistik, daha güncel biçimi ile veri bilimi, bilgisayar teknolojisi ve doğa bir bütün hâlinde öğretim materyali olarak farklı branşlardaki öğretmenlere ve öğrencilerine aktırılabilir.
İstatistik eğitimi her geçen gün değer kazanmaktadır. Bu nedenle, eğitiminin kalitesinin de yüksek olmasını gerekmektedir (Özdemir, 2014). Tablo 1-3'te de görüldüğü gibi, tüm öğretim branşları ve kademelerinde istatistik konularına verilen önem artmaktadır. Ancak, birçok öğrenci tarafından istatistik halen öğrenilmesi zor ve sevilmeyen bir alan olarak görülmektedir (Garfield ve Ben-Zvi, 2008). TÜBİTAK 4004 Doğa Eğitimi ve Bilim Okulları kapsamındaki "İstatistiği Doğada Öğren” projesinde, sınıf dışında doğa eğitimi ile istatistik öğretiminin harmanlanarak aktarılması a maçlanmıştır.

TÜBİTAK 4004 Doğa ve Bilim Okulları kapsamındaki "İstatistiği Doğada Öğren" etkinliği, doğa, İstatistik bilimi ve teknoloji konularında farkındalık yaratmak amacıyla öğretmenlere uygulanmıştır. Etkinlikte yer alan istatistiksel konuların gözlem ve uygulamalarla anlatılmasına imkân sağlanmış ve Ilgaz Dağı Milli Parkı, Tosya Dipsiz Göl Tabiat Parkı, Kastamonu Pınarbaşı İlçesi’nde yer alan Horma Kanyonu ve Ilica Şelalesinde kara ve tatlisu ekosistemleri üzerinde örnek uygulamalar ile aktarılmıştır. $\mathrm{Bu}$ etkinler ile bilgilendirme, bilinçlendirme, geliştirme, uyarma, dengeleme, koruma vb. süreçler sağlanarak katılımc1 36 ögretmende bu yönde olumlu davranışların geliştirilmesi hedeflenmiştir.

\section{YÖNTEM}

\section{1. Örneklem}

Çalışmanın örneklemini, TÜBİTAK 4004 Doğa Eğitimi ve Bilim Okulları kapsamında TÜBİTAK, Tarım Orman Bakanlığı, Ilgaz Dağı Milli Parklar Müdürlüğü tarafından desteklenen 516623 nolu "İstatistiği Doğada Öğren" projesine katılan, MEB'e bağglı okullarda ça lışan, farklı il ve branşlardaki 36 öğretmen oluşturmaktadır. 1317 başvuru arasından projeye ilgi, başvuruların ve cinsiyetin ağırlıklı olduğu gruplar dikkate alınarak 36 kişinin seçimi gerçekleştirilmiş̧ir. Katılımcılara ait cinsiyet ve medeni durum dağılımlan sırasıyla Şekil 1.a ve 1.b'de gösterilmiştir. Buna göre, katılımcıların \%70'inin kadın öğretmenler ve \%57,6'sının bekarolduğu söylenebilir.

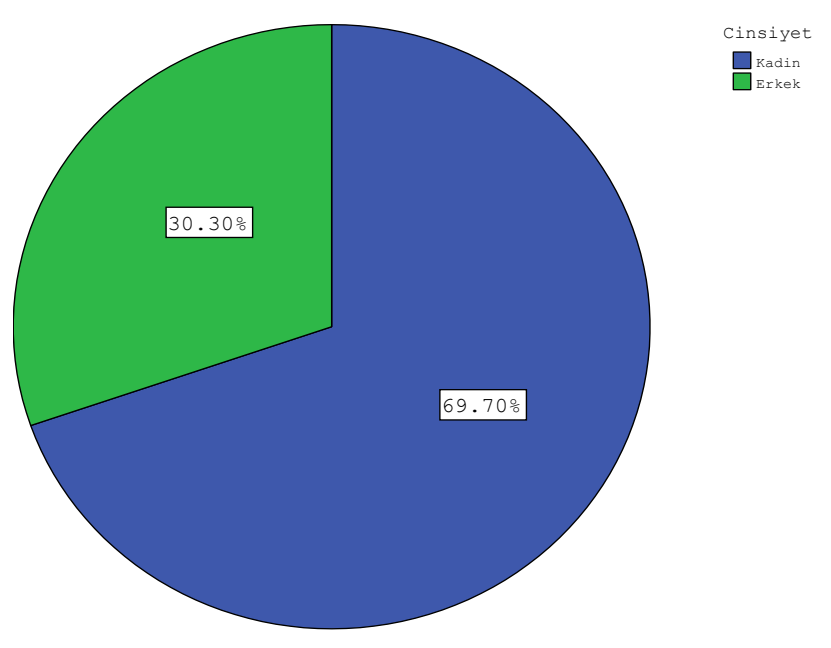

Şekil 1.a. Öğretmenlerin cinsiyet da ğılımları 


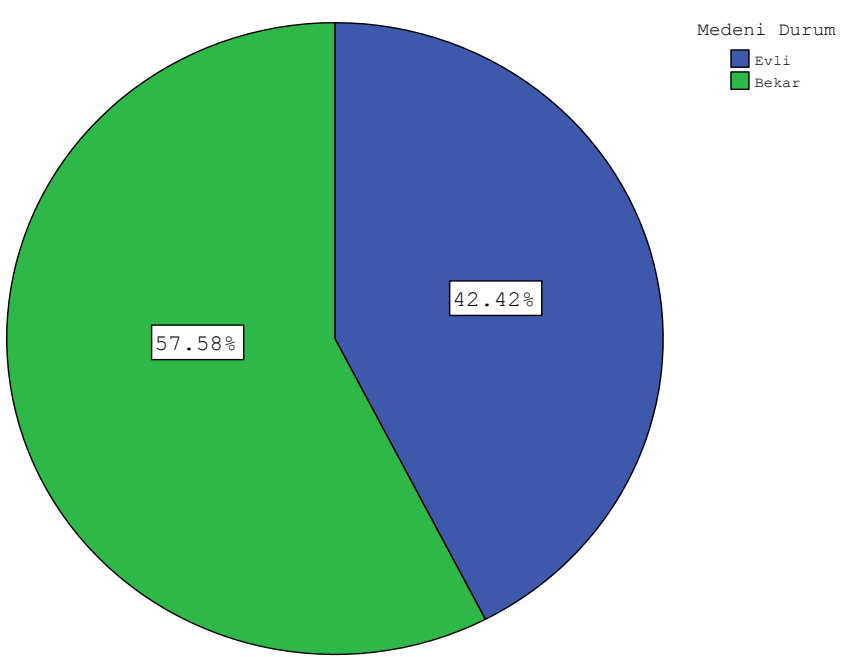

Şekil 1.b. Öğretmenlerin medenidurum dağılımlan

Şekil 2.a'da öğretmenlerin eğitim düzeylerinin ve Şekil 2.b'de meslekteki deneyimlerinin (yıl) dağılımları gösterilmiştir. Buna göre, öğretmenlerin $\% 51,5$ 'inin yüksek lisans eğitimi gördüğ̈ ve \%42,9'unun öğretmenlik mesleğindeki yılllk deneyiminin 5 veya daha az olduğu sonucuna ulaşılmıştır.

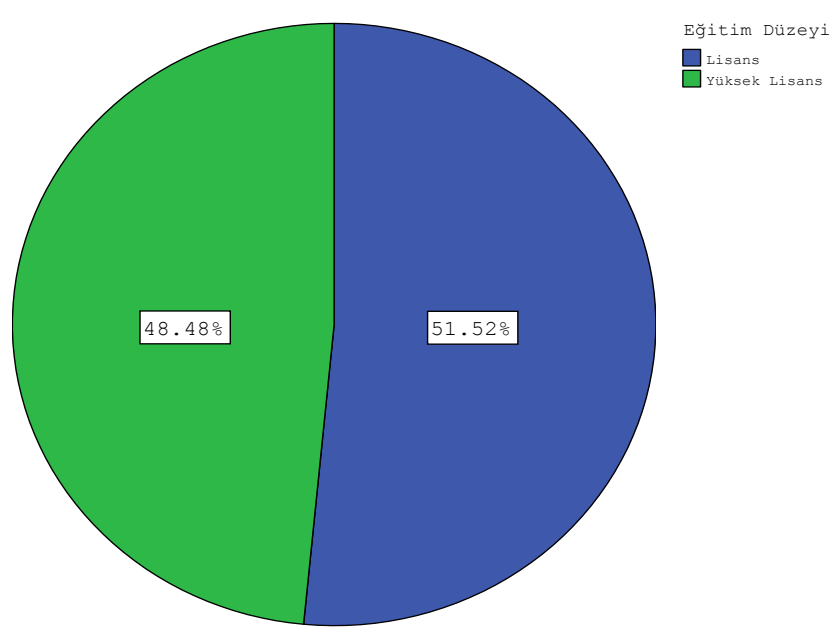

Şekil 2.a. Öğretmenlerin eğitim düzeylerinin da ğılımlar

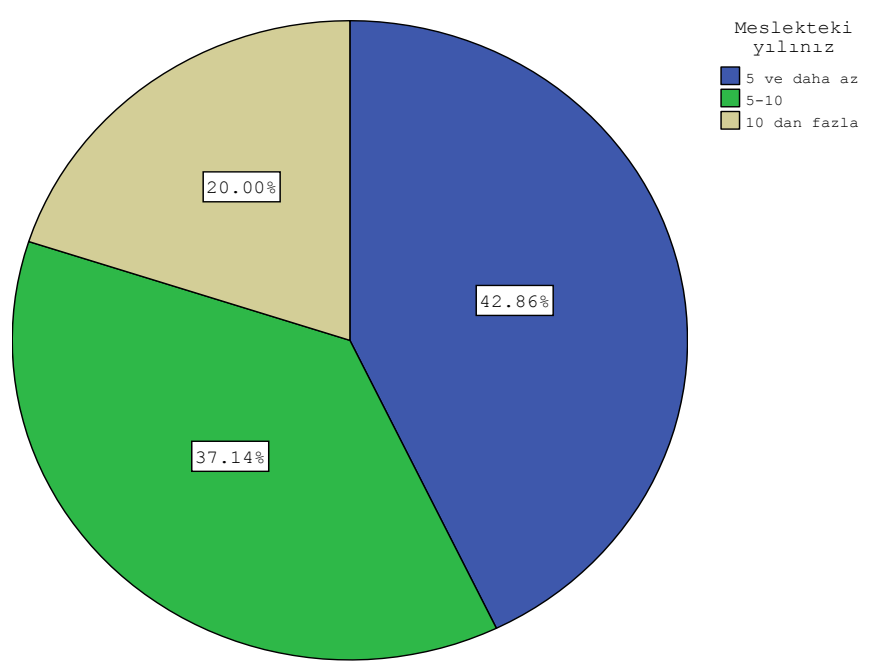

Şekil 2.b. Öğretmenlerin mesleki deneyim da ğılımları
Proje etkinlikleri, farklı düzeydeki öğretim programlarına uygun olacak biçimde ta sarlanmıştır. Etkinliklerde, öğretim programına para lelolarak ögretmenlerin doğal yaşamı, kara ve su ekosistemlerini tanıması koruması, doğa ve istatistik ile etkileşiminin sa ğlanması hedeflenmiştir. İstatistik bütün branşlarda toplanan verilere uygulanabilecek yardımcı bir disiplin özelliğini de taşıması nedeniyle farklı branşlardaki tüm öğretmenlerin etkinlikler için uygun olduğu düşünülmüştür. Şekil 3 'te projeye katılan öğretmenlerin branşlarına göre da ğılımları verilmiştir.

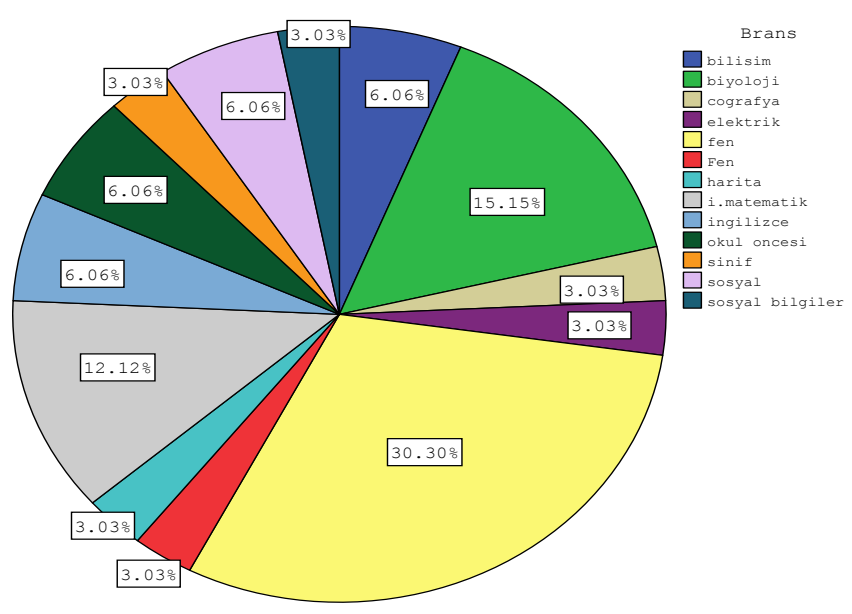

Şekil 3. Öğretmenlerin branşlarına göre da ğılım yüzdeleri

Şekil 3 incelendiğinde öğretmenlerin \%30,3'ünün fen bilimleri, \%15,1'inin biyoloji ve \%12,1'inin coğrafya öğretmeni olduğu görülmektedir. Öğretmenlerin cinsiyet durumları ve sınıf seviyeleri Tablo 4'te verilmiştir.

Tablo 4. Katılımcı öğretmenlere a it temel ista tistikler

\begin{tabular}{lcccc}
\hline & Min & Max & Ortalama & St. Sapma \\
\hline Yaş & 23 & 50 & 30,917 & 5,045 \\
\hline Meslekteki y1l & 0 & 10 & 6,94 & 1,770 \\
\hline $\begin{array}{l}\text { Daha önce katıldı̆̆ } \\
\text { doğa eğitimi sayısı }\end{array}$ & 0 & 2 & 0,111 & 0,398 \\
$\begin{array}{l}\text { Daha önce katıldığı } \\
\text { istatistik eğitimi sayısı }\end{array}$ & 1 & 28 & 7,730 & 5,416 \\
\hline
\end{tabular}

Tablo 4'e göre etkinliğe katılan öğretmenlerin yaş ortalamasının 30 yıl olduğu, ortalama olarak meslekte 7 yıllık deneyimli oldukları, neredeyse hiç doğa eğitimine katılmadıkları ve ortalama $8 \mathrm{kez}$ istatistik içerikli eğitim aldıkları görülmektedir. Öğretmenlerin doğa eğitimine katılım sayılarının düşük olması, TÜBİTAK 4004 Doğa Eğitimi ve Bilim Okulları kapsamında seçilen katılımcılann daha önce bu kod ile başka bir etkinliğe katılmamış olmasından kaynaklanmaktadır.

"İstatistiği Doğada Öğren" etkinlik değerlendirme anketi EK 1'de verilmiştir. Bu anketteki 5'li likert ölçeği kullanılarak hazırlanan sorulara verilen cevapların genel ortalaması 4,81 olarak elde edilmiștir. Buna göre katılımcıların eğitimden genel olarak çok memnun olduğu sonucuna ulaşılmıştır. Kadın ve erkek öğretmenlerin sorulara verdikleri cevapların ortalama değerleri arasında cinsiyet açısından fark olup olmadığının belirlenebilmesi için öncelikle Kolmogorov-Smirnov ve Shapiro-Wilk parametrik olmayan testleri için normallik varsayımı 
Tablo 5. Cinsiyete göre verilen cevapların orta la ma puanlanna ait normallik testleri sonuçlanı

\begin{tabular}{lcccccc}
\hline & \multicolumn{3}{c}{ Kolmogorov-Smirnov Testi } & & \multicolumn{2}{c}{ Shapiro-Wilk Testi } \\
\hline Cinsiyet & İstatistik & Sd & p-Değeri & İstatistik & Sd & p-Değeri \\
\hline Kadın & 0,238 & 25 & 0,001 & 0,821 & 25 & 0,001 \\
\hline Erkek & 0,228 & 11 & 0,003 & 0,765 & 11 & 0,003 \\
\hline
\end{tabular}

Tablo 5'e göre, kadın ve erkek öğretmenlerin sorulara verdikleri ortalama puanları Kolmogorov-Smirnov ve Shapiro-Wilk testleri p-değerlerine göre $(\mathrm{P}=0,001<0,05$ ve $\mathrm{P}=0,003<0,05) \% 5$ yanılma düzeyinde normal dağılmamaktadır. Bu nedenle cinsiyetlere göre ortalama puanlar arasında fark olup olmadığının belirlenmesi için parametrik olmayan testlerden Mann-Whitney $U$ testi kullanılmıştır. Mann-Whitney U testi sonuçları Tablo 6 ve Tablo 7'de verilmiștir:

Tablo 6. Cinsiyete göre verilen cevapların Mann-Whitney U testi rank değerleri

\begin{tabular}{llcc}
\hline Cinsiyet & N & Ortalama Rank & Rank Toplamı \\
\hline Kadın & 25 & 18,22 & 455,50 \\
\hline Erkek & 11 & 19,14 & 210,50 \\
\hline Toplam & 36 & & \\
\hline
\end{tabular}

Tablo 7. Cinsiyete göre verilen cevapların Mann-Whitney U Testi sonuçları

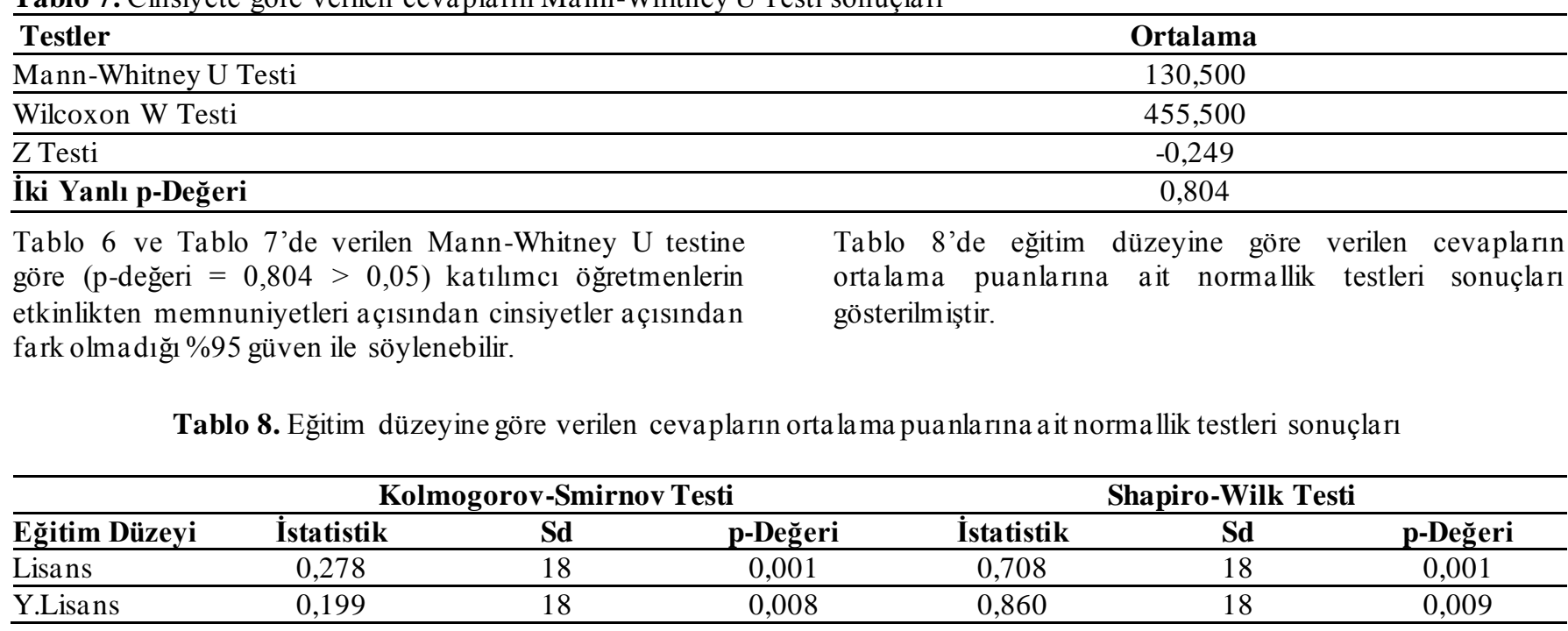

Tablo 8 incelediğinde, Kolmogorov-Smirnov ve ShapiroWilk testleri $\mathrm{p}$-değerlerine göre $(\mathrm{p}=0,001<0,05$ ve $\mathrm{p}=$ $0,009<0,05)$, lisans mezunu ve yüksek lisans mezunu olan öğretmenlerin sorulara verdikleri ortalama puanlarının normalda ğılmadığı $\% 5$ yanılma düzeyinde söylenebilir. Bu nedenle eğitim düzeyine göre sorulara verilen ortalama puanlar arasında fark olup olmadığı Mann-Whitney $U$ testi ile belirlenmiş, sonuçlar Tablo 9 ve Tablo 10' da özetlenmiştir:

Tablo 9. Eğitim düzeyine göre verilen cevaplara ait Mann-Whitney Utesti rank değerleri

\begin{tabular}{llcc}
\hline Ĕ̆itim Düzeyi & N & Ortalama Rank & Rank Toplamı \\
\hline Lisans & 18 & 20,83 & 375,50 \\
\hline Yüksek Lisans & 18 & 16,17 & 291,00 \\
\hline Toplam & 36 & & \\
\hline
\end{tabular}

Tablo 10. Eğitim düzeyine göre verilen cevaplara ait Mann-Whitney U Testi sonuçları

\begin{tabular}{lc}
\hline Testler & Ortalama \\
\hline Mann-Whitney U Testi & 120,000 \\
\hline Wilcoxon W Testi & 291,000 \\
\hline Z Testi & -1.374 \\
\hline Íki Yanlı p-Değeri & 0,169 \\
\hline
\end{tabular}


Tablo 9 ve Tablo 10'da sunulan Mann-Whitney U testi sonuçlarına göre (p-değeri $=0,169>0,05)$ öğretmenlerin etkinlikten memnuniyetlerinde eğitim düzeyleri açısından fark olmadı̆̆ $\% 95$ güven ile söylenebilir.
Tablo 11-13'te ise, doğa eğitimi alan ve almayan öğretmenlerin değerlendirme anketinde verdikleri cevaplara ait puanların ortalamaları arasında fark olup olmadığı a raştırılmıştır.

Tablo 11. Doğa eğitimi a lan ve a lmayanların ceva plarının orta lama puanlarına a it normallik testleri sonuçları

\begin{tabular}{lcccccc}
\hline & \multicolumn{2}{c}{ Kolmogorov-Smirnov Testi } & \multicolumn{3}{c}{ Shapiro-Wilk Testi } \\
\hline Doğa Ĕgt. & Istatistik & Sd & p-Değeri & İstatistik & Sd & p-Değeri \\
\hline Hay1r & 0,263 & 25 & 0,000 & 0,766 & 25 & 0,000 \\
\hline Evet & 0,276 & 11 & 0,003 & 0,888 & 11 & 0,003 \\
\hline
\end{tabular}

Tablo 12. Doğa Eğitimi a lan/a lmayanlara öğretmenlere ait cevapların Mann-Whitney U testi rank değerleri

\begin{tabular}{llcc}
\hline Doğa Ĕ̆itimi & N & Ortalama Rank & Rank Toplamı \\
\hline Hayır & 25 & 19,84 & 496,00 \\
\hline Evet & 11 & 15,45 & 170,00 \\
\hline Toplam & 36 & & \\
\hline
\end{tabular}

Tablo 13. Doğa Eğitimi a lan/a lmayanlara öğretmenlere ait cevapların Mann-Whitney U Testi sonuçlan

\begin{tabular}{|c|c|}
\hline Testler & Ortalama \\
\hline Mann-Whitney U Testi & 104,000 \\
\hline Wilcoxon W Testi & 170,000 \\
\hline Z Testi & $-1,189$ \\
\hline İki Yanlı p-Değeri & 0,234 \\
\hline $\begin{array}{l}\text { Tablo } 11-13 \text { 'e göre Mann-Whitney } U \text { testi p-değeri }=0,234 \\
>\quad 0,05 \text { olduğundan ögretmenlerin etkinlikten } \\
\text { memnuniyetlerinde doğa eğitimine katılıp katılmamaları } \\
\text { açısından fark olmadığ } \% 95 \text { güven ile söylenebilir. }\end{array}$ & $\begin{array}{l}\text { Özet olarak, yapılan değerlendirme anketindeki 5'li likert } \\
\text { ölçeğindeki sorulara göre, öğretmenlerin "İstatistiği Doğada } \\
\text { Öğren" eğitiminden memnun oldukları, cinsiyete, eğitim } \\
\text { düzeylerine ve herhangi bir doğa eğitimine } \\
\text { katılıp/katılmama durumlarına göre memnuniyetlerinin } \\
\text { değişmediği }\end{array}$ \\
\hline
\end{tabular}

\subsection{Katılımcı görüş yazıları}

“İstatistiği Doğada Öğren” etkinliğine katılan öğretmenlerin etkinlik bitiminde uygulanan anket formunda ayrıca kişisel görüş ve önerilerini dile getirmeleri, en beğenilen etkinlikleri belirtmeleri istenmiştir. $\mathrm{Bu}$ eğitim kapsamında yer verilen bazı temel etkinlikler aşa ğıdaki gibi temel içerikleri ile Tablo 14'te özetlenmiştir:

Tablo 14. Eğitimde Yer Verilen Bazı Temel Etkinlikler ve İçerik Özeti

\begin{tabular}{|c|c|}
\hline Etkinlik Adı & Etkinlik İçerik Özeti \\
\hline Ekolojik İstatistikler & $\begin{array}{l}\text { Temel İstatistiksel Kavramlar (Orta lama, Varyans, Mod, Medyan), Grafikler } \\
\text { (Pasta, Histogram, Çubuk, Saçılım), SPSS Programı ile Veri Analizi }\end{array}$ \\
\hline Doğanın İlişkileri & Korela syon ve Regresyon Analizleri, PAST programı ile Veri Analizi \\
\hline Sudan İstatistikler & Sucul Ekosistemlerin Canlıları ve İstatistiksel Ölçümlerin Elde Edilmesi \\
\hline Toprak Ana ile Eğlenceli İstatistikler & Toprak Türleri, Toprak Analizi ve İstatistikleri \\
\hline Sürüngenlerin Gizemli Dünyas1 & Sürüngen Örnekleri, Yaşamları ve İsta tistiki Bilgileri \\
\hline Tabiat Okulu & Ağaç Yaş, Çap Ölçümü, Veri Toplama \\
\hline Doğa Bir Bilmece & $\begin{array}{l}\text { Yakala-Tekrar Yakala Örnekleme Yöntemi, Ekolojik Tahmin, Kart Eşleme, } \\
\text { Y1lan ve Merdiven Oyunu ile Olasılık Hesapları }\end{array}$ \\
\hline Yapay Zeka ile Doğayı Kurtarmanın Yolları & $\begin{array}{l}\text { Doğa Bilimlerinde Kullanılan Makine Öğrenme, Yapay Zeka Tekniklerinin } \\
\text { Tanıtılması }\end{array}$ \\
\hline Oryantiring & Doğada Harita ile Yön ve Hedef Bulma \\
\hline Doğal Çeşninin İstatistiği & Biyoçeşitlilik Araştırmalarında İstatistikselHesaplamalar \\
\hline Doğanın Denklemi & Regresyon Modelinin PAST ile Tahmini \\
\hline İklim Değişiyor, Doğa Direniyor & İklim Değişikliği ve Etkileri, İklim Değişiklik Verilerinin Temini ve Analizi \\
\hline $\begin{array}{l}\text { Katılımcılara uygulanan etkinlik değerlendir } \\
\text { en beğendikleri etkinlerden bahsetmeleri is } \\
\text { anketin sonuçlarına göre, katılımcıların \% }\end{array}$ & $\begin{array}{lllll}\text { anketinde } & \text { "Oryantiring", } \% 47 \text { 'si “Tabiat } & \text { Okulu", } & \text { \%44’ü } \\
\text { Imiştir. Bu } & \text { "Sürüngenlerin Gizemli Dünyası", \%36's1 "Doğa Bir } \\
\text { 'si en çok } & \text { Bilmece, Sudan İstatistikler, Ekolojik İstatistikler" ve }\end{array}$ \\
\hline
\end{tabular}




\subsection{Röportajlar}

“İstatistiği Doğada Öğren” etkinliğine katılan öğretmenler ile etkinlik bitiminde röportajlar gerçekleştirilmiş ve bu röportajların bazıları aşağıdaki gibi kendi ifadeleri ile verilmiştir:

Ö1. (Fen bilimleri öğretmeni): "Projenin amacına uygun olarak gerçekleştiğini düşünüyorum. İstatistiği doğada öğrenerek farkındalık, belirli bir bilinç kazandırılmaya çalış1ld1 ögretmenler için. Bu doğrultuda hedeflerin kendim adına gerçekleştiğini düşünüyorum. En dikkatimi çeken etkinlik ağaçlar ile ilgili yapılan Tabiat Okulu etkinliği oldu. Ağaçların çapının ölçüldüğü, yaşının belirlendiği ya da bir ormanda ağaçların oranıyla ilgili yüzdelikleriyle ilgili birtakım bilgiler verilmişti. Orası benim için en can alıcı olan noktasiydi.

$\mathrm{Bu}$ eğitimin doğa temelli olması benim de branşımı kapsıyor. Fen bilimleri alanı zaten doğadaki sistemleri anlatıyor. Bu yönden ögrencilerle birçok etkinlik ve atölye yapılabileceğini düşünüyorum. Örneğin bize en son gün oynatılmış olan yılan merdiven oyunu oynatılabilir ya da veri toplama yöntemleri aynı şekilde kullanılabilir."

Ö2. (Coğrafya Öğretmeni): “Coğrafya öğretmeniyim zaten coğrafya alanında lisans düzeyinde eğitim alırken istatistik dersini bir nebze de olsa almıştık. Ama bilakis doğada birçok canlı üzerinde, ekosistemdeki diğer varlıklar üzerinde istatistiğin bu derece önem arz edebileceğini bu proje sayesinde daha net bir şekilde gördüm. Gerçek anlamda hem nicel hem de nitel verilere dayanarak istatistik bilgisinin son derece önemli olduğunu öğrendik. Bu anlamda gerçekten de mutluyum. Bütün uygulamalar hem eğitimsel anlamda hem de kişisel anlamda son derece olumluydu. Bunları kesinlikle okul ve çevresinde öğrencilerimize aktarma konusunda bizler bilgi edindik, tecrübe edindik. Mesleki kariyerlerimizde mesleki haya tlarımızda bunu son derece kullana ca ğız.

Etkinliklerin hemen hemen hepsi okullarda uygulanabilir. Uygun zemin hazırlandığı taktirde ki, doğa anlamında Türkiye son derece bakir topraklara sahip bir ülke olduğun için hemen hemen her anlamda uygulanabileceğini düşünüyorum. Bir ağacın yaşının tespit edilmesi, doğada nesli tükenmekte olan hayvanların istatistiklerle analiz edilmesi hem bir öğrenciye doğa sevgisinin aşılanması hem de doğaya karşı nasıl da vranılması gerektiği hususunda son derce bilgiler sundu. Kesinlikle okuluma gittiğim zaman öğrencilerimle buna ve buna benzer projelerle, a razi uygulamalarıyla bunları uygulama aşamasında son derece iyimserim, uygulayacağım. Gerçekten istatistiğin doğayla entegre edilebileceğini ben bu proje sayesinde çok iyi gördüm ve gözlemledim. Umarım bu projelerin devamı gelir. Hem öğretmenlere hem diğer sektörde çalışan tüm eğitmenlere bir faydası olabileceğini düşünüyorum."

Ö3. (Biyoloji Öğrretmeni): "Eğitimde sadece biyoloji gibi fen bilimleri gibi branşların değil de okul öncesi, sınıf, matematik gibi öğretmenlerin de doğa bilimleriyle ilgili bilgi sahibi olması bu eğitim sayesinde açıkçası beni mutlu etti. Biyoloji branşında olduğum için doğa bilimleriyle ilgili bazı kısımlar daha önce karşılaştığım kısımlardı. Ama tekrar görmek ve diğer branş öğretmenlerimle birlikte zaman geçirmek benim için güzeldi. İstatistik kısmı ise okulda biraz diğer derslerle sıkıcı oluyordu açıkçası. Bu şekilde eğlenceli hale getirilmiş oldu. Ve ben açıkçası kendim veri analiz edebilecek düzeye geldiğim için memnunum.

Oryantiringi çok beğendim. Çünkü hem bilgiyi çok güzel kullandık konumları bulmak için hem de güzel bir yarış da vardı gruplar arasında. Zaten bütün etkinliklerde hem grup olarak hem diğer gruplarla iletişimimiz çok güzeldi. Bence etkinlikler güzel seçilmişti bu eğitim için. Hatta biz de kullanabiliriz bu eğitimleri veya benzerlerini doğa eğitimi için gittiğimiz yerlerde. "

Ö4. (Fen bilimleri öğretmeni): "Normalde ben de derslerimde çok sınıfa bağlı kalmayı sevmiyorum. Hani olabildiğince, imkânlar elverdiğince dişarda eğitim. En azından okul bahçesinde veya bilim parklarında vesaire eğitimleri gerçekleştirmeye çalışıyorum. $O$ yüzden gerçekten çok güzeldi ve bana da böyle bir fikirler, 1şıklar yaktı beynimde. Gayet güzeldi.

Mesela yeni bir sınıf geldiğinde ben de öğrencileri yeni tanıdığımda ve karma bir yerlerden geldiği zaman ilk olan balonla tanışma etkinliğini mutlaka uygularım. Küçük sın $1 \mathrm{f}$ grupları için belki okuma-yazma oranları çok iyi olmadığından şekillerle ifade edebilirler balonların üzerine kendi simgelerini koyarlar ve o şekilde tanışma sağlayabiliriz ki çok eğlenirler, çok akılda kalır. Aynı şekilde bu bilgi kartları vardı işte kuşlar ve latince isimleri vb. bunları fen bilimlerinde birçok alanda kullanabilirim işte hayvan hücresi, bitki hücresi, bunların içindeki organelleri tanımlamada öğrencilerin çok ilgisi çeker. Grup grup çalışma lar yapabilirler. Bu yılan-merdiven oyunu tüm konularda, neredeyse fen bilimlerinin tüm konularında uygulanabilir. Eğitimde hem iç a lanı hem de dış alanı çok aktif bir şekilde kullandık. Hani sadece içeriye bağlı da kalmadık. Dışarıyla bütünleştirilmesi içerdeki etkinliklerin veya konuların farklı mekanlarda a nla tılması çok güzeldi."

Ö5. (Matematik Öğretmeni): "Matematik öğretmeni olduğum için özellikle istatistik boyutu üzerinden eğitim a lacağım diye gelmiştim buraya. Ama alttan alttan biyolojik k1sm1, ekosistemleri de bize eğlenerek öğretildiğini fark ettim. Demek ki bu, kendimizde bunu yapabilirmişiz olgusu oluştu. Net bir şeye odaklanmak tek bir ders yerine, onun alttan farklı ders ve disiplinler arası bağdaştırabiliriz diye düşünüyorum. En dikkat çeken etkinliğimiz Caretta caretta şarkısıydı. Yani belli bir konuyu anlatırken bunu dediğim gibi aynı şeyi belki kendimde uygulamayı düşünüyorum. Matematikle ilgili bir teoremi diyeyim veya formülü şarkılaştırıp da öğrenciye aktarmak çok daha akılda kalıcı olur. Çok beğendim. İç uygulama, dış uygulama yaptık. Ben üniversiteyi bitireli zaten 13 y1l falan oldu. 13 y1l önceki düşüncem çok daha farklıydı. Şu konuda, işte akademisyenler, profesördür, doçenttir ulaşılamaz kişilerdir. Yani 'yaklaşamazsın, bir şey söylemeye korkarsın' tabusunu bura da yıktım. Hoca la rımız sa ğ olsun, akademisyenlerimiz hepsi bizden daha neşeliydi mi diyeyim, bizi daha çok eğitime katmaya çalıştı. Bu tabuyu yıktıkları için öncelikle kendilerine o şekilde teşekkür etmek istiyorum. Artık öğrencilerime daha farklı şekilde bunu yansitacağım.” 
Ö6. (Fen Bilimleri Öğretmeni): "İstatistik ve doğa kavramını ben çok fazla kafamda birleştirememiştim açıkçası buraya gelmeden önce. Doğada 'neyin istatistiği nasıl yapılıyor?' diye düşünmüştüm. Daha çok sayısal veriler nasıl toplanıyor, bunlar nasıl yorumlanıyor, nerede kullanılıyor diye düşünmüştüm. $\mathrm{Bu}$ eğitim sayesinde bu istatistik ve doğanın aslında birbiriyle iç içe olduğunu çok rahat bir şekilde anladım. Doğadaki birçok verinin kullanılabileceği, bu verilerle neler yapabileceğimizi, işte biyoçeşitlilik türlerimizin belirlenmesinde, ondan sonra belirli bir bölgede hani orman yangını olduğunda hangi bölgeyi daha rahat kurtarabileceğimizin bile aslında ista tistiki verilere dayandığını öğrenmiş olduk. Hani birçok alanda istatistikten faydalanılabileceğini, doğa da bunun için uygun alanlardan biri olduğunu çok rahat öğrendim eğitim sayesinde. Genel anlamda uygula mala ra baktığımda yeterli buldum yanibeni doyurdu açıkça sı yani.

En çok korelasyon üzerine, regresyon üzerine neler yapabiliriz? Bunları gördüm. Okulda bunları nasıl kullanabilirim. Onların üzerine etkilendim diyebilirim. Bana katkı sağladı. Ayrıca sürüngenler üzerine yapılan çalışmalarile sürüngenleri daha yakından tanıdım. Biz daha çok okulda 4006 projeleri yapıyoruz. Hani bazen TÜBİTAK'ın düzenlediği proje yarışmaları oluyor. Belki onlarla ilgili yani, doğada bu projelere, burada öğrendiklerimi katarak birazcık daha istatistiki çalışma şeklinde biraz daha bilimsel bir şekilde çalışmalara destekleyebilir diye düşündüm. Bilim fuarlarında kullanılabilir diye düşündüm yani."

“13 yıllık öğretmenim, 2008'den beri öğretmenlik yapıyorum. Biz üniversitelerde güzel bir eğitim alıyoruz ancak bu eğitim okula gittiğimizde bazen karşılığını bulmuyor. Bazen de böyle yillar içerisinde insan öğretmenlik mesleğinin içerisinde üniversiteden uzaklaşabiliyor. Ben devamlı bir öğretmenin üniversite ile bağının olması gerektiğini düşünüyorum. Bu tarz eğitimlerde hani öğretmenle akademisyenleri bir araya getiriyor ve öğretmenlerin nasıl diyeyim; mesleki anlamda yeniliklerden, yeniliklerin farkına varmasını sağlıyor, yeniliklerden haberdar olmasını sağlıyor. O yüzden yani öğretmenin gelişimi için çok önemli görüyorum yani. Öğretmeni canlandırıyor diyebilirim. Hatta ben 2013 yılında ilk kez böyle bir etkinliğe başvurmuştum. Hani 2008-2012 arasıyla 2013 sonrası benim için epey değişti yanifarklı oldu."

Ö7. (Beden Eğitimi Öğretmeni): "Genel olarak faaliyetler çok eğiticiydi. İstatistikle bu şekilde doğanın birleştirilmesi bence önemli. Çünkü daha görsel olarak akılda kalıcı olduğunu düşünüyorum. İşitsel, görsel zekâ bazında baktığımızda ben görsellikte daha çok iyi olduğumu düşünüyorum. Etkinliklerde hep yaparak öğrenmeye yönelik olduğu için, istatistik konusunda hani hiçbir fikrim yokken, şu an artık bir fikrim var diyebiliyorum. Benim için oryantiring eğitimi en keyifli etkinlikti. Haritayla yön bularak hedefleri aldık ve bunu grup halinde yaptık. Bu yüzden hem grup halinde yapmış olmamız hem de işin içine harita girmesi ve en sonunda da bunu istatistiki verilerle aldığımız balonu -balonlardı hedeflerimiz- balonların üzerindeki istatistiki kodlarla güzel şeyler yaptığımızı düşünüyorum.

$\mathrm{Ne}$ yaparım ne ederim, 'gidiyorum evet ama istatistik öğreneceksin, nerede uygulayacaksın?’ Bu çok önemli bir soruydu benim için. Açıkçası doktora tezimde büyük bir yer vereceğime inanıyorum artık buna. Hani daha -basit düzeyde diyeyim - basit bir düzeyde tez yazmaktansa artık istatistikle birleştirerek kendi tezimi de daha zenginleştirebilirim daha günümüze uyarlamış olabilirim. Çünkü günümüzün artık istatistikle yönetildiğinin farkına vardım. Fikrimin olmadığı konularda, SPSS program 1 olsun, PAST programı olsun veya yapay zekâ olsun bu konularda fikir edinmiş oldum."

Ö8. (Sosyal Bilgiler Öğretmeni): Çok uzak bir yerden geldim ben. Yaklaşı $1300 \mathrm{~km}$ Şanlıurfa'dan. 'Acaba değecek mi?' diye bu soruyu kendime sordum. Çünkü hem okul haftası, okul açıldı hem bir yorgunluk oluyor, yol yorgunluğunu diye düşündüm. Fakat buraya geldiğimde bunların hepsinin geçtiğini fark ettim. Çünkü çok samimi bir ortam gördüm. Sonra akademik hayatıma çok katk1 sağlayan dersler, eğitimler gördüm burada. Doğaya herkes bakabilir ama herkes göremez. İstatistik kısmı da budur. İşte insanların göremediği veya kaçırdığı bazı ayrıntıları çalışıp veya ölçüp, hesaplayıp insanlara sunmaktır, bir veri aracıdır. İstatistik budur. Bir çoban da çok fazla vakit geçirebilir doğada ama bir istatistikçi olamaz. Bu yüzden böyle bir eğitim için geldim. Ben çok uzun yıllardır doğa ile iç içe olan bir insanım. Bu eğitime kadardoğaya bakışaçım daha farklıydı. Sadece hani doğal güzellikleri görmek veya tarihi güzellikleri görmek a macıyla gelmiştim. Fakat buraya geldikten sonra artık toprakların, kayaçların yapısını; a ğaçların yaşı, boyu gibisinden ayrıntılara dikkat etmeye başladım. Bu hem eğlenceli, güzel bir şey hem de yorucu bir şey. Artık doğaya gelip dinlenmek yerine biraz da etrafa da bakmak da gerekiyor artık. Bu yüzden benim için çok verimli bir eğitim oldu. Yılanlardan çok korkarım. Baya da çekinirim. Hocamız böyle sürüngenler konusunu anla tmıştı. Bir yılanı getirmişti böyle... Biraz detaylı inceleme fırsatı buldum. Bu etkinlik benim için çok başarılı bir etkinlik oldu. Hayvanları yakından gördüm. İlk defa bir yılanı elim e aldım mesela. İşte üzerindeki desenleri görebilme fırsatı yakaladım işte zehri konusunda detaylara girdik. Keza diğer sürüngenler için de. Bu benim için çok önemli ve güzel bir etkinlik oldu.

Yüksek lisans öğrencisiyim. Nicel bir çalışmam var. SPSS konusunda çok fazla ders alamadım. Burada en azından SPSS'in temel çalışma işlevlerini görme fırsatı yakaladım. Keza, okulumun bulunduğu bölge Şanlıurfa bölgesi, orman bakımından çok fakir bir bölge. Bir tane ormanımız var, o da yapay bir orman. Öğrencilere hep orman sevgisini aşılamak işte orman bilinci oluşturmak için öğrencilerimi oraya götürmeyi düşünüyorum. Bunlar bu eğitimin kazanımları benim için. Tabi ki daha farklı kazanımları olabilir ama en bariz şu an aklıma gelen kazanımlar bunlar."

\subsection{Kurgusal ve uygulamalı eğitim içerikleri}

Etkinliklere katılan öğretmenlerin ve bunun yanı sıra sosyal medya hesapları ile projeyi takip eden öğretmenlerin etkinlikler sonunda yapılan çalışmalardan esinlenerek kurgusal eğitim içerikleri hazırlaması, sınıflarında öğrencilerine adapte etmesi istenmiştir. $\mathrm{Bu}$ çalışmalar sonucunda öğrencilerin bilime bakış açılarında, yaratıcı, bilimsel düşünme ve sosyal becerilerinde değişim gözlemlenmiştir. Katılımcılar tarafından tasarlanan bir kurgu eğitim içeriği örneği aşa ğıda verilmiştir: 
Etkinlik: STEM ile canlıların sınıflandırılmasında karar ağacı oluşturma

1. Bilișsel Sürecte STEM Disiplinlerine Ait Kazanımlar:

$>$ Matematik

$\checkmark \quad$ Birinci dereceden bir bilinmeyenli denklem ve eşitsizliklerin çözüm kümelerini bulur.

$\checkmark$ Oran ve orantı kavramlarını kullanarak problemler çözer.

$\checkmark$ Denklemler ve eşitsizlikler ile ilgili problemler çözer.

$\checkmark \quad$ Merkezî Eğilim ve Yayılım Ölçüleri

$\checkmark$ Verilerin Grafikle Gösterilmesi

Fen Bilimleri

$\checkmark$ Canlıların ortak özelliklerini irdeler.

$\checkmark$ Canlıların Çeșitliliği ve Sınıflandırılması

$\checkmark \quad$ Canlı Âlemleri ve Özellikleri

İstatistik

$\checkmark \quad$ İstatistiksel yazılım program larını (IBM SPSS STATISTICS 23 veya RAPIDMINER STUDIO) temel düzeyde kullanmayı öğrenir.

$\checkmark$ İstatistiksel yazılım programlarından (IBM SPSS STATISTICS 23 veya RAPIDMINER STUDIO) karar a ğacı oluşturmasını temel ve orta düzeyde öğrenir.

$\checkmark \quad$ İstatistiksel yazılım programında (IBM SPSS STATISTICS 23 veya RAPIDMINER STUDIO) oluşturduğu karar ağacının görsel düzenlemesini yapar.

Sosyal Ürün Kazanımları: Takım içerisinde çalışabilme, iş planı yapabilme, disiplinler arası ilişki kurabilme, etkili sunum yapabilme, teknolojiyi ve bilimi günlük hayatta kullanabilme, araştırma ve geliştirme çalışma la rını yapabilme

2. Kullanilan Materyaller:

> Bilgisayar, İnternet, MS Office programları, IBM SPSS STATİSTİCS 23, Kağıt ve kalem.

3.Problem:

$>$ Bir insan çevresindeki canlıları ne kadar iyi tanır ve onları ne kadar iyi sınıflandırırsa kendi gelişimine o derecede katkı sağlar. Bu sebeple çevremizdeki canlıları sınıflandırabileceğimiz bir karar a ğa cı ta sarlayınız.

4.Meslek, Görev ve Sorumluluklar:

- Matematikçi • Biyolog • İstatistikçi • Araştırma ana listi • Veri madencisi

5.Ders İceriği: Problem ve Sınırlamalar:

$>$ Çevremizdeki canlıları sınıflandırmayı nasıl yapariz?

$>\mathrm{Bu}$ sınıflandırmayı yapmak için gerekli bilgi ve birikimler nelerdir?

$>$ Gerekli bilgi ve birikimi olmayan insanların canlıları sınıflandırması mümkün müdür?

$>$ Bir insanın çevresindeki diğer canlıları sınıflandırması ve tanımasının öneminedir?

$>$ Her insanın sınıflandırma yapabilmesi için teknolojiyi nası1 kullanabiliriz?

$>$ Karar a ğacı ne demektir?
$>$ İstatistiksel yazılım programlanı ne ișe yarar? Karar ăgacı ve istatistiksel yazılım programlarından bahsedilir. Karar ăgaçları ile canlıların sınıflandırılması arasında bağlantı kurulur. Teknolojinin hayatımızdaki öneminden bahsedilir. Insanların akıll telefonlarından, tabletlerinden veya bilgisayarlarindan takip edebilecekleri bir karar ă̆acının işlevinden bahsedilir.

\section{Bilgi Edinme:}

$>$ Canlılarnasil siniflandirilır?

$>$ Canlıları sınıflandırma kriterleri nelerdir?

$>$ Her canlı sınıfının spesifik özellikleri nelerdir?

$>$ Karar ağacı nasıloluşturulur?

> İstatistiksel yazılım programları ile karar ağacı nasil oluşturulur?

> Karar a ğacında kullanabileceğimiz sınıflandırma kriterleri neler olabilir?

\section{Fikir Geliștirme:}

> Proje geliştirme için çalışma grupları oluşturunuz.

> Gruplarda ortaya atılacak fikirlerin ve izlenecek yollar ile ilgili tartışma ortamı sa ğlayınız.

$>$ Tartışmalarda grupların her elemanına söz vermeye dikkat ediniz.

\section{$\underline{\text { 8.Ürün Gelistirme: }}$}

$>$ Karar ağa cının a lgoritma sını oluşturmada na sıl b ir yol izleneceğinin sorusunu sorunuz.

$>$ Benzer bir a lgoritma için örnekler veriniz.

> Algoritma hesaplamaları için canlıları hangi kriterlere göre sınıflandırılacağını sorunuz.

\section{Paylașma ve Yansitma:}

$>$ Katılımcıların kendi kendilerinin puanlamasını değerlendirmesini isteyiniz.

$>$ Karar ağac1 algoritması için bir sunum hazırlanmasını takip ediniz.

$>$ Projenin sunumunu gerçekleştirilmesini sa ğlayınız.

> Katılımcıların oluşturdukları karar ăgacı algoritmasını diğer grupların üyelerine denettirmelerini öneriniz.

$>$ Sosyal medya da karar ăga cı a lgoritmasını bilim sel bir çerçevede sunulma sını teşvik edilir.

Ayrıca projeye ilgi duyarak iletişime geçen Şanlıurfa'da görev yapan sınıf öğretmeninin proje süresince tasarladığı doğadaki materyaller ile veri gruplama ve sınıflandırma çalışması Şekil 4'te sunulmuştur. 

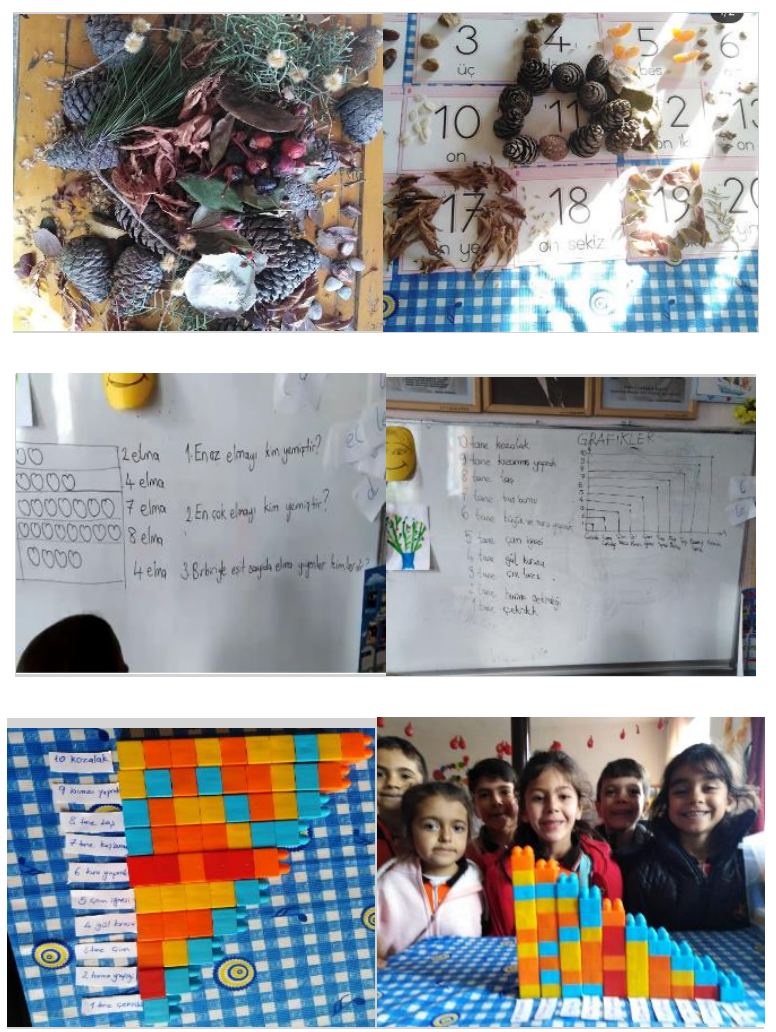

Şekil 4. Projemizdeki Eğitimleri Uygulayan Örnek Çalışmalar

Katılımcı ögretmenler tarafından tasarlanan bir istatistik soru örneği de Şekil 5 'te verilmiştir:

SORU:

Standart sapma aşağıdaki işlemler takip edilerek hesaplanır:

1) Verilerin aritmetik ortalaması bulunur.

2) Her bir veri ile aritmetik ortalama arasındaki farkın kareleri toplanır.

3) Bulunan toplam veri sayısının bir eksiğine bölünerek karekökü alınır.

Katamonu'da düzenlenen bir Tübitak projesindeki eğitmenlerin gerçekleştirdiği etkinlik ve sunum sayıları aşağıdaki tabloda verilmiştir.

\begin{tabular}{|c|c|c|c|c|c|}
\hline Eğitmenler & $\begin{array}{c}\text { Gamze } \\
\text { Hoca }\end{array}$ & $\begin{array}{c}\text { Kürşat } \\
\text { Hoca }\end{array}$ & $\begin{array}{c}\text { Ecir } \\
\text { Hoca }\end{array}$ & $\begin{array}{c}\text { Güvenç } \\
\text { Hoca }\end{array}$ & $\begin{array}{c}\text { Halil } \\
\text { Hoca }\end{array}$ \\
\hline $\begin{array}{c}\text { Etkinlik ve } \\
\text { sunum sayısı }\end{array}$ & 3 & 2 & 3 & 1 & 1 \\
\hline
\end{tabular}

Buna göre projede gerçekleştirilen etkinlik ve sunum sayılarının standart sapması kaçtır?
(A) 1
B) $\frac{\sqrt{3}}{2}$
C) $\sqrt{3}$
D) $\frac{\sqrt{6}}{2}$
E) $\sqrt{6}$

Şekil 5. Katılımcı Öğretmen Tarafından Tasarlanan Soru

\section{TARTIȘMA VE SONUÇLAR}

Günümüzde, veriye ulaşma kısmının kolay olmasına karşılık doğru veriyi seçme ile toplama ve yorumlama kısımlarının daha zor ve önemli olduğu İstatistik içerikli öğretim programlarında giderek daha çok ilgi görmektedir (Shaughnessy, 2007; Gattuso ve Otta via ni, 2011). İstatistik biliminin önemli bir yere sahip olması eğitimi ile kalitesi ve yeterliliği kısımlarının da yüksek olmasını gerektirmektedir (Özdemir, 2014). Günlük hayatta bireyler gazete, dergi ve internet siteleri aracılığıyla hızlıca yayılan çok çeşitli verilerle karşılaşmakta ve bu verilerden anlam çıkarmak durumundadir.

İstatistiksel bilgilerin günlük yaşamda hep karşımıza çıkması ve önemlilik arz etmesi sebebiyle toplumlar da harekete geçmektedir. Bu sebeple, öğretim programlarında istatistiksel becerilere daha çok yer verilmekte ve istatistiksel düşünme ve okuryazarlık kısmına vurgu ya pılmaktadır. Bu değişimin yansımaları ülkemizde de okul öncesinden üniversiteye kadar seviyede veri ile ilgili kazanımlara daha da fazla yer verilmesi şeklinde görülmektedir.

Öğrencilerin kendi topladıkları verilerle çalışması, verileri anlamaları ve açıklamaları için daha fazla çaba sarf etmelerini sağlar. Projeler, öğrencilerin kendi verilerini elde etmeleri ve çalışmaları için en uygun yollardan birisidir. Projeler sayesinde öğrencilerde yaşam becerileri güçlenir, motivasyon artar ve daha derin bir öğrenme süreci oluşur. $\mathrm{Bu}$ sebeple, öğrenciler istatistiksel araştırma sürecini yaşayabilecekleri ve tecrübe elde edecekleri projelerde yer almalidir.

İstatistik öğretiminde kavramların anlamları, veriden ya rarla narak tahmin ve çıkarımlar elde etme, öneri, tartışma ve yorum kısımları, hesaplamalar, matematiksel beceriler ve grafik çizimleri kısımlarına göre daha çok üzerinde durulmalıdır. Aynı zamanda, öğrenci merkezli yöntemler yaratılmalıdır. Problem oluşturma, hipotezler kurma, örneklemi belirleme, verileri toplama, tahmin ve çıkarsamalar elde etme gibi istatistiksel süreçlerin ögrenciler tarafından yapıldığı ortamlar sa ğlanmalıdır.

Son olarak, teknoloji eğitimin her alanı ve aşamasında kullanılmalı ve yaygınlaştırılmalıdır. İstatistik öğretiminde de yazılımlardan yararlanılmalı ve öğretim aracı olarak kullanılmalıdır. Günlük hayattan karşımıza çıkan durum la r örneklenerek istatistikle gerçek yaşam ortaklığından bahsedilmelidir. Aynı zamanda teknoloji sayesinde, ögrenciler hesaplamalara harcayacakları zamanları çıkarsama, yorum ve tartışma kısımlarında kulla nmalıdır.

\section{KAYNAKLAR}

Akay, C. (2013). Ortaokul öğrencilerinin yaparakyaşayarak ögrenme temelli TÜBİTAK 4004 Bilim Okulu Projesi sonrası bilim kavramına yönelik görüşleri, Mersin Üniversitesi, Eğitim Fakültesi Dergisi, 9(2), 326-338.

Akkoç, H., Yeşildere İmre, S. (2015). Teknolojik Pedagojik Alan Bilgisi Temelli Olasılık ve İstatistik Öğretimi. Ankara: Pegem Akademi.

Aslan, Z., Doğdu, S. (1993). Eğitim Teknolojisi Uygulamaları ve Eğitim Araç-Gereçleri. Ankara: Tekışık Ofset.

Buluş Kırıkkaya, E., Bozkurt, E., İmalı, B. (2011). Örnek bir öğrenme ortamı: TÜBİTAK destekli ilköğretim öğrencileri bilim yaz okulu. I. Uluslararası Ĕ̆itim Programları ve Öğretim Kongresi, Anadolu Üniversitesi, Eskişehir. 
Chance, B., Ben-Zvi, D., Garfield, J., Medina, E. (2007). The role of technology in improving student learning of statistics. Technology Innovations in Statistics Education 1(1).

Cobb, G. W., Moore, D. (1997). Mathematics, Statistics and Teaching. The American Mathematical Monthly, 104,801-823.

Demiralp, N. (2007). Coğrafya eğitiminde materyaller ve 2005 coğrafya dersi ögretim program1. Kastamonu Eğitim Dergisi, 15(1), 373-384.

Erden, M. (1998). Sosyal Bilgiler Öğretimi. İstanbul: Alkım Yayınevi.

Feyzioğlu, B., Özenoğlu Kiremit, H., Öztürk Samur, A.,

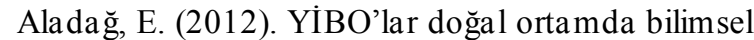
düşünüyor. Eğitim ve Öğretim Araştırmaları Dergisi, 1(4), 65-74.

Gal, I. (2004). The Challenge of Developing Statistical Literacy, Reasoning and Thinking. The Netherlands: Kluwer academic publishers.

Garfield, J. (1995). How the students learn statistics. International Statistical Review, 63(1), 25-34, 1995.

Garfield, J., Ben-Zvi, D. (2008). Developing students' statistical reasoning: Connecting research and teaching practice. Springer Science \& Business Media.

Güler, T. (2009). Ekoloji temelli bir çevre eğitiminin öğretmenlerin çevre eğitimine karş1 görüşlerine etkileri. Ĕgitim ve Bilim, 34, 151.

Hırça, N. (2013). Üstün yetenekli öğrencilerin yaz bilim kamp1 deneyimleri. Üstün Yetenekliler Eğitimi Araştırmaları Dergisi 1(1), 22-30.

Kaya, Z. (2006). Öğretim Teknolojileri ve Materyal Geliştirme (2. Bask1). Ankara: Pegem Yayıncılık

Keleş, Ö., Uzun, N., Varnacı Uzun, F. (2010). Öğretmen a daylarının çevre bilinci, çevresel tutum, düşünce ve davranışlarının doğa eğitimi projesine bağlı değişimi ve kalıcılığının değerlendirilmesi. Elektronik Sosyal Bilimler Dergisi, 9(32), 384-401.

Koparan, T. (2015). İstatistiksel okuryazarlık modelleri ve bileşenlerinin incelenmesi. Turkish Journal of Education, 4(3), 16-22.

Koparan, T., Akınc1, M. (2015). İstatistik öğretiminde yeni yaklaşımlar. Ĕgitim ve Öğretim Araştırmaları Dergisi, 4(1), 36-45.

Malik, S. (2015). Undergraduates' statistics anxiety: $A$ Phenomenological Study. The Qualitative Report, 20(2), 120-133.
Marulcu, D., Saylan, A., Güven, E. (2014). 6. ve 7. sınıf öğrenciler için gerçekleştirilen "Küçük Bilginler Bilim Okulu"nun değerlendirilmesi. Mustafa Kemal Üniversitesi Sosyal Bilimler Enstitüsü Dergisi, 11(25), 341-352.

MEB (2009). Matematik Dersi (6-8.Sinflar) Öğretim Programı ve Matematik Dersi (9-12.Sinıflar) Öğretim Programı. Ankara: Milli Eğitim Bakanlığı.

MEB (2013). Ortaokul Matematik Dersi (5, 6, 7 ve 8. Sınıflar) Öğretim Programı ve Ortaöğretim Matematik Dersi (9, 10, 11 ve 12. Sinıflar) Öğretim Programı. Ankara: Milli Eğitim Bakanlığı.

Oğurlu, D., Alkan, H., Ünal, Y., Ersin, M. Ö., Bayrak, H. (2013). Çevre ve doğa eğitimlerinin coğrafya eğitimine katkıları: Ide Projeleri örneği. 3rd International Geography Symposium -Geomed, Symposium Proceedings, 498-508.

Ozaner, S. (2004). Türkiye'de okul dişı çevre eğitimi ne durumda? Neler yapilmalı? V. Ulusal Ekoloji ve Çevre Kongresi, Abant İzzet Baysal Üniversitesi \& Biyologlar Derneği, Bolu.

Özdemir, O. (2010). Doğa deneyimine dayalı çevre eğitiminin ilköğretim öğrencilerinin çevrelerine yönelik algı ve davranışlarına etkisi. Pamukkale Üniversitesi Eğitim Fakültesi Dergisi, 27, 125-138.

Tekbıyık, A., Şeyihoğlu, A., Sezen Vekli, G., Birinci Konur, K. (2013). Aktif ögrenmeye dayalı bir yaz bilim kampının öğrenciler üzerindeki etkilerinin incelenmesi. International Journal of Social Science. 6(1); 1383-1406.

TÜBİTAK (2019a) 2237-a Doğa Bilimlerinde İstatistiksel Modelleme Teknikleri ve Uygulamaları, Proje No: 1129B371900490.

TÜBİTAK (2019b) 4004 Doğa Eğitimi ve Bilim Okulları, İstatistiği Doğada Öğren, Proje No: 516623.

Wallman, K. K. (1993). Enhancing statistical literacy: Enriching our society. Journal of the American Statistical Association, 88(421),1-8.

Watson, J. M. (2006). Statistical literacy at school: Growth and goals. Mahwah, NJ: Lawrence Erlbaum.

Yenilmez, K. (2016). Öğretmen adaylarının akademik özyeterlikleri ve matematik öğretimine yönelik özyeterliklerinin bazı değişkenler açısından incelenmesi. Dicle Üniversitesi Ziya Gökalp Eğitim Fakültesi Dergisi, (29), 316-323. 
EK 1. İstatistiği Doğada Öğren” Etkinlik Değerlendirme Anketi

\section{TÜBİTAK 4004 “İstatistiği Doğada Öğren” Projesi}

\section{Değerlendirme Anketi}

Değerli Katılımc1,

Bu anket, "İstatistiği Doğada Öğren” projesi kapsamında düzenlenen eğitimlere yönelik olarak, eğitim ile ilgili düşüncelerin tespit edilmesine ve sonraki eğitim faaliyetlerinin verimliliğinin arttırılmasına yöneliktir. İçtenlikle cevap vermeniz ve boş madde bırakmamanız a raştırmanın sonuçları ve niteliği açısından önemliolup, sonuçlar başka bir a maçla kullanılm ayacak ve gizli tutulacaktır. Anket yaklaşık 15 -20 dakika sürmektedir. Katkılarınızdan dolayı teşekkür ederim.

Prof. Dr. Gamze ÖZEL KADILAR

1. Yaşınızı belirtiniz:

2. Cinsiyetinizi belirtiniz: Kadin ( )

3. Meslekteki yılınızı belirtiniz:...............

4. Eğitim düzeyinizi belirtiniz: Lisans ( ) Yüksek Lisans ( ) Doktora ( )

5. Branşınızı belirtiniz:...............

6. Daha önce istatistik eğitimi temelli katıldığınız etkinlik sayısı: ............

7. Daha önce doğa eğitimi temelli katıldığınız etkinlik sayısı:

Aşa ğıdakimaddelerden size uygun olanı işa retleyiniz.

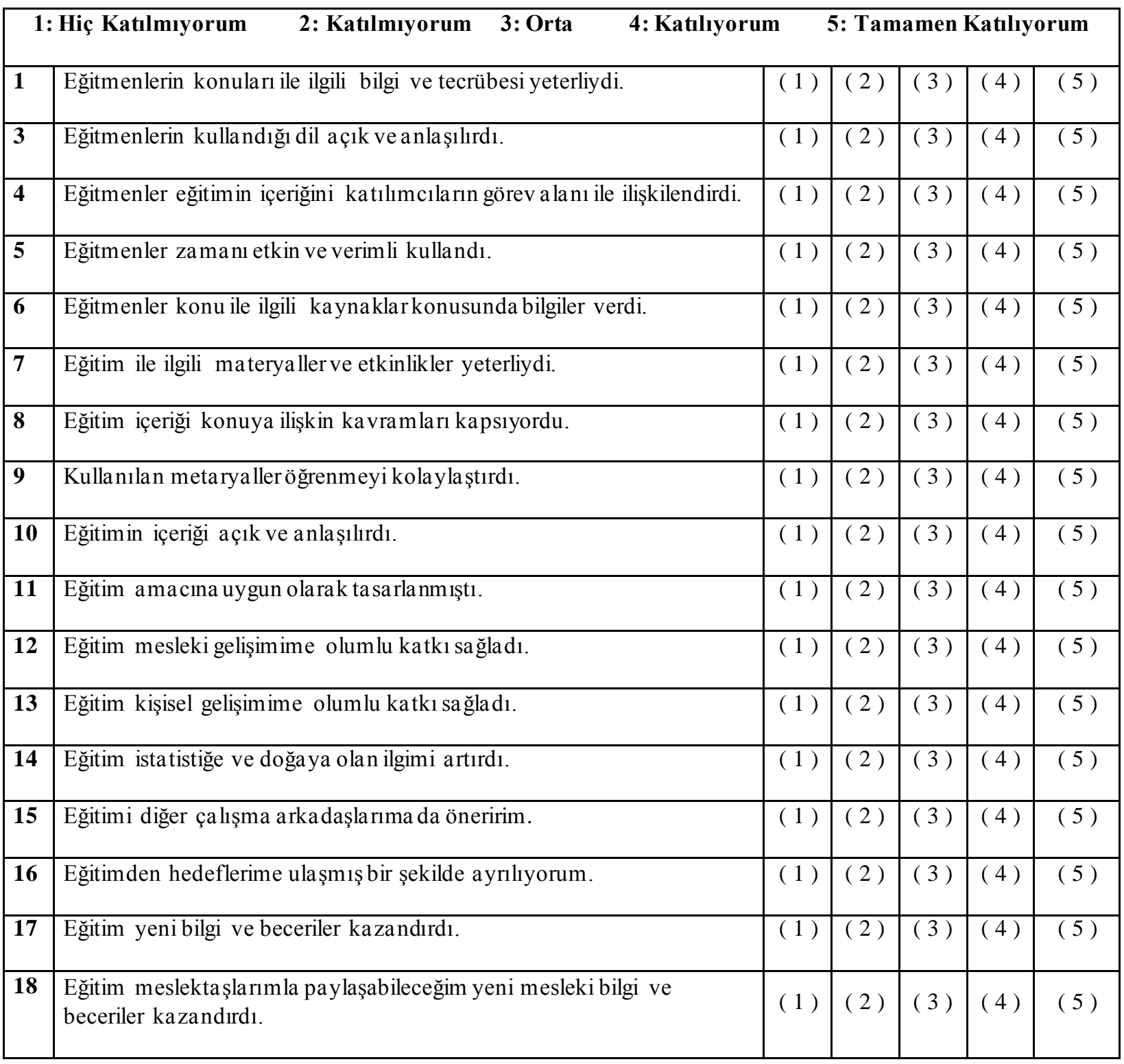


19. En sevdiğiniz etkinlikler hangileridir?

20. İstatistik ile ilgili en çok hangi bilgileri öğrendiniz? Hangi bilgileri öğrencilere aktarabilirsiniz?

21. Öğrendiğiniz bilgiler 1şı̆̆ında doğa sevgisi ve bilincinin yaygınlaşması konusunda neleryapmayı hedefliyorsunuz?

22. İsta tistik biliminin sevdirilmesi ve yaygınlaşmasına ça lışmalarınıza na sıl yansıtmayı düşünüyorsunuz?

\section{Eğitimle ilgili eklemek diğer istediğiniz hususlar varsa belirtiniz.}

